\title{
ANALISIS PENERAPAN TARIF PROGRESIF PAJAK KENDARAAN BERMOTOR PADA UNIT PELAKSANA TEKNIS DAERAH (UPTD) KOTA MANADO
}

\author{
Mario Y. Thomas ${ }^{1}$, David P. E. Saerang ${ }^{2}$, Jessy D. L. Warongan ${ }^{3}$ \\ 1,2,3 Jurusan Akuntansi, Fakultas Ekonomi dan Bisnis, Universitas Sam Ratulangi, Jl. Kampus Bahu, Manado, \\ 95115, Indonesia \\ E-mail :marioyohanisthomas@yahoo.com
}

\begin{abstract}
Vehicle Tax is the major contributor to the Original Local Government Revenue, with a progressive tax rate. Vehicle is a crucial asset because the price per unit is relatively high. The tax function fulfillment in this policy is very influential to the wealth of people as a vehicle user, whether it is for entrepreneur or non-entrepreneur. Every province is unique by economy, social, cultural and other factors that are obviously differentiating the tax policy implementation. This research analyzes the implementation of vehicle progressive tax rate policy in Manado City Local Technical Operating Unit and explains the obstacles faced along with the efforts to overcome. This research is done by the qualitative approach with descriptive analysis. Research result describes the policy implementation specifically by some aspects related to vehicle tax, explains the obstacles faced along with the efforts to overcome.
\end{abstract}

Keywords : progressive tax rate, vehicle tax

\section{PENDAHULUAN}

Dalam pendapatan sebuah negara, pajak merupakan kontributor terbesar dibandingkan sumber-sumber pendapatan yang lain. Kebijakan desentralisasi yang diterapkan pemerintah diiringi dengan penyerahan kewenangan pengelolaan pajak dari pusat ke daerah. Salah satu basis pajak yang dikelola daerah adalah Pajak Kendaraan Bermotor, dan di Provinsi Sulawesi Utara tarif Pajak Kendaraan Bermotor berlaku secara progresif. Dalam penetapan kebijakan pajak, pemerintah selalu mengacu kepada fungsi pajak dalam mencapai tujuannya. Kendaraan bermotor yang merupakan objek Pajak Kendaraan Bermotor adalah aset krusial baik bagi masyarakat pengusaha maupun bukan pengusaha, dan sangat banyak dari mereka yang memiliki aset kendaraan bermotor lebih dari satu. Dari segi bisnis, ilmu akuntansi pajak sangat memperhatikan perkembangan kebijakan perpajakan oleh pemerintah untuk dapat mengelola perpajakan suatu instansi dengan baik. Mengingat bahwa tujuan pajak adalah untuk kesejahteraan rakyat, maka pemerintah diharapkan dapat menyelaraskan kesejahteraan rakyat dengan kesejahteraan pengusaha. Di dalam suksesnya penerapan sebuah kebijakan pajak, terdapat peran besar oleh masyarakat sebagai pelaku pajak.

Alasan pemilihan Kota Manado untuk diteliti disebabkan oleh beberapa hal, yakni karena Kota Manado merupakan ibukota Provinsi Sulawesi Utara dan memiliki jumlah penduduk terbanyak sejak tahun 2007 sesuai data Badan Pusat Statistik di Provinsi Sulawesi Utara. Kota Manado juga memiliki pertumbuhan ekonomi dalam jajaran tertinggi di antara Kabupaten/Kota lainnya di Provinsi Sulawesi Utara sejak tahun 2013, dengan pertumbuhan ekonomi tertinggi pada tahun 2013 dan 2016 (Badan Pusat Statistik, 2017 : 383). Dalam 4 tahun terakhir jumlah kendaraan bermotor di Kota Manado meningkat setiap tahunnya, baik untuk jenis kendaraan bermotor roda 2 dan 3, dan jenis kendaraan bermotor roda 4 ke atas. 


\section{TINJAUAN PUSTAKA}

Akuntansi. Akuntansi terdiri dari tiga aktivitas dasar, yaitu mengidentifikasi, mencatat, dan melaporkan kejadian-kejadian ekonomi dari sebuah organisasi kepada pengguna-pengguna yang berkepentingan (Kieso, et al., diterjemahkan, 2016: 2).

Akuntansi Pajak. Akuntansi pajak adalah ilmu untuk menetapkan besarnya pajak terutang berdasarkan laporan keuangan yang disusun oleh perusahaan (Agoes dan Trisnawati, 2013 : 10).

Pajak. Pajak adalah iuran rakyat kepada negara berdasarkan undang-undang yang dapat dipaksakan tanpa imbalan langsung dan digunakan untuk membayar pengeluaran umum (Soemitro dalam Mardiasmo, (2018: 1).

Fungsi Pajak. Menurut Mardiasmo (2018 : 1) ada dua fungsi pajak, yaitu:

1. Fungsi Budgetair. Sebagai salah satu sumber penerimaan pemerintah.

2. Fungsi Regulerend. Sebagai alat untuk mengatur dalam berbagai bidang, seperti sosial, ekonomi, dan lain-lain.

Pajak Kendaraan Bermotor. Menurut Undang-Undang No. 28 Tahun 2009, Pajak Kendaraan Bermotor adalah pajak atas kepemilikan dan/atau penguasaan kendaraan bermotor.

Nama, Objek, dan Subjek Pajak Kendaraan Bermotor. Objek Pajak Kendaraan Bermotor menurut Pasal 4 Peraturan Daerah No. 7 Tahun 2011 adalah kepemilikan dan/atau penguasaan kendaraan bermotor. Kendaraan bermotor adalah kendaraan bermotor beroda beserta gandengannya, yang dioperasikan di semua jenis jalan darat dan kendaraan bermotor yang dioperasikan di air dengan ukuran isi kotor 5 GT (lima gross tonnage) sampai dengan 7 GT (tujuh gross tonnage), yang bekerja dengan mengubah suatu sumber daya energi tertentu menjadi tenaga gerak kendaraan bermotor yang bersangkutan. Yang dikecualikan dari pengertian kendaraan bermotor adalah kereta api, kendaraan bermotor yang semata-mata dipergunakan untuk pertahanan dan keamanan negara, dan kendaraan bermotor yang dimiliki dan/atau dikuasai kedutaan, konsulat, perwakilan negara asing dengan asas timbal balik dan lembaga-lembaga internasional yang memperoleh fasilitas pembebasan pajak dari pemerintah. Subjek Pajak Kendaraan Bermotor menurut Pasal 5 Peraturan Daerah Provinsi Sulawesi Utara No. 7 Tahun 2011 adalah orang pribadi atau badan yang memiliki dan/atau menguasai kendaraan bermotor, yang disebut Wajib Pajak Kendaraan Bermotor. Yang bertanggungjawab atas pembayaran pajak untuk orang pribadi adalah orang yang bersangkutan, kuasanya atau ahli warisnya. Sedangkan yang bertanggung jawab untuk badan adalah pengurus atau kuasanya.

Dasar Pengenaan, Tarif, dan Cara Penghitungan Pajak Kendaraan Bermotor. Berdasarkan Peraturan Daerah Provinsi Sulawesi Utara Nomor 7 Tahun 2011, cara penghitungan Pajak Kendaraan Bermotor adalah sebagai berikut:

$$
\text { Pokok PKB = DPPKB x Tarif PKB }
$$

Di mana DPPKB (Dasar Pengenaan Pajak Kendaraan Bermotor) diperoleh dari: NJKB x Bobot

NJKB (Nilai Jual Kendaraan Bermotor) ditentukan berdasarkan Harga Pasaran Umum (HPU) dari suatu kendaraan bermotor pada minggu pertama bulan Desember tahun pajak sebelumnya. Bobot adalah angka yang menunjukkan kadar kerusakan jalan dan/atau pencemaran lingkungan akibat penggunaan kendaraan bermotor. Khusus untuk kendaraan bermotor yang digunakan di luar jalan umum, termasuk alat-alat berat dan alat-alat besar serta kendaraan di air, dasar pengenaan pajak kendaraan bermotor adalah NJKB. Penghitungan dasar pengenaan Pajak Kendaraan Bermotor ditinjau kembali setiap tahun. Mengenai kepemilikan kendaraan bermotor seperti ditetapkan dalam Pasal 8 Peraturan Daerah Provinsi Sulawesi Utara Nomor 7 Tahun 2011 tentang Pajak Daerah, kepemilikan 
kendaraan bermotor didasarkan atas nama dan/atau alamat yang sama dan mengacu pada KTP.

Tarif Progresif Pajak Kendaraan Bermotor. Berdasarkan Pasal 7 Peraturan Daerah Provinsi Sulawesi Utara No. 7 Tahun 2011, tarif progresif Pajak Kendaraan Bermotor ditetapkan dengan dijelaskan dalam tabel berikut.

Tabel 1. Tarif Progresif Pajak Kendaraan Bermotor pada UPTD Kota Manado

\begin{tabular}{|c|c|}
\hline Kepemilikan & Tarif PKB \\
\hline Pertama & $1,5 \%$ \\
\hline Kedua & $2 \%$ \\
\hline Ketiga & $2,5 \%$ \\
\hline Keempat & $3 \%$ \\
\hline Kelima dan seterusnya & $3,5 \%$ \\
\hline
\end{tabular}

Wilayah Pemungutan. Dalam Pasal 10 Peraturan Daerah Provinsi Sulawesi Utara Nomor 7 Tahun 2011 tentang Pajak Daerah, Pajak Kendaraan Bermotor yang terutang dipungut di wilayah daerah tempat kendaraan bermotor didaftarkan, bersamaan dengan penerbitan Surat Tanda Nomor Kendaraan Bermotor. Pemungutan pajak tahun berikutnya dilakukan di kas daerah atau bank yang ditunjuk oleh Gubernur.

\section{METODE PENELITIAN}

Jenis Penelitian. Penelitian ini menggunakan pendekatan kualitatif. Peneliti ingin memperoleh data langsung dan lebih mendalam dari fiskus terkait penerapan kebijakan beserta kendala yang dihadapi dan upaya mengatasinya, lewat aspek-aspek yang terdapat pada kebijakan tarif progresif Pajak Kendaraan Bermotor dan tujuan penerapannya.

Tempat dan Waktu Penelitian. Tempat penelitian yaitu Kantor Unit Pelaksana Teknis Daerah Kota Manado yang berlokasi pada Jalan 17 Agustus. Waktu penelitian yaitu pada bulan Mei sampai bulan Juli 2018.

\section{Jenis, Sumber dan Metode Pengumpulan Data}

Jenis Data. Jenis data yang dikumpulkan dalam penelitian ini adalah data kualitatif. Data kualitatif dalam penelitian ini berupa hasil wawancara dengan pihak instansi gambaran umum instansi, sistem dan prosedur pelayanan dan kebijakan-kebijakan pemerintah.

Sumber Data.Sumber data dari penelitian ini adalah data primer. Data primer dalam penelitian ini diperoleh dari Unit Pelaksana Teknis Daerah Kota Manado, berupa data hasil wawancara dengan pihak instansi, gambaran umum instansi, struktur organisasi, kebijakankebijakan pemerintah.

Metode Pengumpulan Data. Metode pengumpulan data dalam penelitian ini yaitu sebagai berikut :

1. Dokumentasi. Dokumentasi digunakan untuk mengumpulkan data kemudian ditelaah. Data yang didokumentasikan peneliti yaitu gambaran umum instansi berupa sejarah, visi dan misi, struktur organisasi, serta sistem dan prosedur operasional instansi.

2. Wawancara. Pertanyaan dalam wawancara mengacu kepada aspek-aspek yang memiliki kaitan dengan tarif progresif, di mana aspek-aspek tersebut merupakan bagian dari Peraturan Daerah Provinsi Sulawesi Utara Nomor 7 Tahun 2011 dan tujuan penerapan kebijakan yang ditinjau melalui fungsi pajak seperti telah dilakukan dalam penelitianpenelitian sebelumnya. Informan yang diwawancarai dalam penelitian ini yaitu fiskus yang bekerja pada UPTD Kota Manado. 
Metode Analisis. Dalam penelitian ini, metode analisis yang digunakan adalah analisis deskriptif. Peneliti mewawancarai penerapan kebijakan serta kendala yang dihadapi dan upaya mengatasinya dengan meninjau aspek-aspek Pajak Kendaraan Bermotor dalam Peraturan Daerah Provinsi Sulawesi Utara Nomor 7 Tahun 2011 tentang Pajak Daerah. Aspek-aspek yang masih kurang, memerlukan penjelasan, ataupun celah-celah penghindaran pajak akan dijabarkan dalam pertanyaan wawancara. Hasil wawancara kemudian dijabarkan secara sistematis dan dibahas untuk menjawab rumusan masalah yang ada.

\section{HASIL PENELITIAN DAN PEMBAHASAN}

\subsection{Hasil Penelitian}

Penerapan Tarif Progresif PKB pada UPTD Kota Manado

Aspek Nama, Objek dan Subjek Pajak Kendaraan Bermotor. Dalam wawancara dikemukakan bahwa Pengusaha Kena Pajak yang merupakan Wajib Pajak Badan dibebaskan dari pengenaan tarif progresif Pajak Kendaraan Bermotor. Fasilitas pembebasan pengenaan tarif progresif Pajak Kendaraan Bermotor tidak diberikan kepada Pengusaha Kena Pajak yang tergolong Wajib Pajak Orang Pribadi.Untuk kendaraan-kendaraan tertentu seperti tipe pickup, truck, dan kendaraan angkutan umum juga mendapat fasilitas pembebasan pengenaan tarif progresif Pajak Kendaraan Bermotor.

Aspek Dasar Pengenaan, Tarif dan Cara Penghitungan Pajak Kendaraan Bermotor. Untuk Harga Pasaran Umum kendaraan bermotor, UPTD Kota Manado berkiblat pada Peraturan Menteri Dalam Negeri (Permendagri) yang dijabarkan pada Peraturan Gubernur (Pergub). Data Harga Pasaran Umum dimutakhirkan secara berkala melalui Kode dan Uraian Kelompok/Jenis dan Merk Kendaraan Bermotor atau coding.

Prosedur pelayanan pembayaran Pajak Kendaraan Bermotor dan Bea Balik Nama Kendaraan Bermotor pada Unit Pelaksana Teknis Daerah Kota Manado yaitu sebagai berikut:

1. Koordinasi/konfirmasi kesiapan sistem, petugas, pedoman.

2. Wajib pajak ke loket informasi untuk mendapat info tentang pembayaran Pajak Kendaraan Bermotor dan prosedur balik nama STNK.

3. Petugas informasi memberi formulir pendaftaran untuk diisi, memberi nomor antrian dan mengarahkan wajib pajak ke loket antrian untuk menunggu panggilan.

4. Petugas pendaftaran memanggil, memeriksa kelengkapan berkas, lalu mengarahkan wajib pajak agar menunggu panggilan petugas bank untuk melakukan pembayaran.

5. Pendaftaran dan penyelidikan berkas oleh petugas kepolisian.

6. Penetapan jumlah Sumbangan Wajib Dana Kecelakaan Lalu Lintas Jalan oleh petugas Jasa Raharja.

7. Petugas SKUM/KOHIR memeriksa kwitansi jual beli dan surat fiskal. Petugas penetapan menetapkan besar pajak sesuai ketentuan.

8. Korektor mengoreksi jumlah pajak, nama, alamat, tanggal jatuh tempo, tahun berlaku, mengisi jumlah STNK, TNKB dan menerbitkan slip bayar.

9. Petugas bank menerima berkas dan slip bayar lalu memanggil wajib pajak untuk membayar.

10. Setelah membayar wajib pajak menunggu di loket penyerahan SKPD dan STNK.

11. Berkas diterima oleh petugas pencetakan untuk menerbitkan SKPD, STNK dan TNKB.

12. Validasi SKPD dan arsip SKPD.

13. Penyerahan SKPD/STNK, TNKB kepada wajib pajak.

Sebelum memperoleh pelayanan pembayaran Pajak Kendaraan Bermotor dan Bea Balik Nama Kendaraan Bermotor, Wajib Pajak wajib memenuhi kelengkapan berkas, yakni:

a. Mengisi formulir;

b. Cek fisik kendaraan bermotor; 
c. Sertifikat NIK (Nomor Identifikasi Kendaraan) atau VIN (Vehicle Identification Number); dan

d. Copy identitas:

1) Perorangan

Tanda jati diri yang sah (asli), bagi yang berhalangan melampirkan surat kuasa.

2) Badan Hukum

Salinan akte pendirian, surat kuasa bermeterai dan ditandatangani oleh pimpinan serta dibubuhi cap badan hukum bersangkutan.

3) Instansi Pemerintah (termasuk BUMN/BUMD)

Surat tugas/surat kuasa bermeterai dan ditandatangani oleh pimpinan serta dibubuhi cap instansi.

UPTD Kota Manado menetapkan kepemilikan kendaraan bermotor berdasarkan nama dan alamat pemilik kendaraan bermotor. Dokumen yang digunakan sebagai acuan dalam menentukan kepemilikan kendaraan bermotor adalah Kartu Tanda Penduduk (KTP). Untuk kendaraan bekas Wajib Pajak dapat menggunakan Surat Izin Mengemudi (SIM) sebagai dasar penetapan kepemilikan kendaraan KTP karena calon pemilik kendaraan bermotor harus berdomisili di Provinsi Sulawesi Utara untuk menjadi pemilik kendaraan bermotor baru.

Aspek Wilayah Pemungutan. Pada UPTD Kota Manado, tarif progresif Pajak Kendaraan Bermotor dikenakan atas dua atau lebih kendaraan bermotor dengan nama dan alamat yang sama, pada wilayah pemungutan yang sama. Tarif progresif Pajak Kendaraan Bermotor tidak dikenakan pada dua atau lebih kendaraan bermotor dengan nama dan alamat yang sama jika kendaraan-kendaraan tersebut terdaftar pada wilayah pemungutan yang berbeda-beda. Sebagai contoh, dua kendaraan dengan nama dan alamat pemilik yang sama, di mana kendaraan pertama terdaftar pada UPTD Kota Manado dan kendaraan kedua terdaftar pada UPTD Kota Amurang, maka pada kendaraan kedua tidak dikenakan tarif progresif Pajak Kendaraan Bermotor karena terdaftar pada wilayah pemungutan yang berbeda dengan kendaraan pertama.

Tujuan Penerapan Tarif Progresif Pajak Kendaraan Bermotor. Pemerintah Provinsi Sulawesi Utara menerapkan kebijakan tarif progresif Pajak Kendaraan Bermotor dengan tujuan untuk menekan pertumbuhan jumlah kendaraan bermotor agar dapat mengurangi tingkat kemacetan di Kota Manado. Sedangkan dalam wawancara diungkapkan tujuan yang lain yaitu untuk kemudahan administrasi, agar ketika masyarakat membeli kendaraan bekas, masyarakat akan langsung melakukan balik nama untuk menghindari pengenaan tarif progresif Pajak Kendaraan Bermotor yang melekat pada kendaraan yang dibeli sehingga ketepatan data dalam sistem dengan kondisi terkini di lapangan akan tetap terjaga. Dengan kemudahan administrasi, di sisi lain Pendapatan Asli Daerah akan meningkat lewat penerimaan Bea Balik Nama Kendaraan Bermotor.

\section{Kendala dalam Penerapan Tarif Progresif Pajak Kendaraan Bermotor serta Upaya yang Dilakukan UPTD Kota Manado dalam Mengatasinya}

Kendala. Dalam penerapan tarif progresif Pajak Kendaraan Bermotor pada UPTD Kota Manado ditemukan kendala-kendala sebagai berikut:

1. Kurang maksimalnya penyebaran informasi tentang kebijakan tarif progresif

Penyebaran informasi tentang tarif progresif Pajak Kendaraan Bermotor belum terlaksana dengan maksimal, karena banyak wajib pajak yang tidak mengetahui bahwa ada kebijakan tarif progresif Pajak Kendaraan Bermotor yang telah berlaku di Provinsi Sulawesi Utara. Masyarakat hanya menyadari tentang kebijakan ini ketika mendapati Pajak Kendaraan Bermotor yang mereka bayar lebih mahal.

2. Kurangnya kepatuhan wajib pajak 
Menurut hasil wawancara, kepatuhan wajib pajak untuk langsung melakukan balik nama saat melakukan pembelian kendaraan bekas sangat kurang. Hal yang sering terjadi yakni wajib pajak yang keberatan karena menganggap bahwa pengenaan tarif progresif per kepemilikan tidak tepat. Contoh yang sering terjadi yakni pada saat kendaraan wajib pajak A dengan kepemilikan pertama dikenakan tarif kepemilikan ke dua, karena kendaraan lama yang telah dijual kepada wajib pajak B belum dilakukan balik nama, sehingga masih tercatat atas nama wajib pajak A. Dalam wawancara dikemukakan bahwa wajib pajak enggan untuk melakukan balik nama kendaraan bermotor saat membeli kendaraan bekas karena merasa Bea Balik Nama Kendaraan Bermotor besar, yaitu sebesar $1 \%$ dari Nilai Jual Kendaraan Bermotor.

3. Perbedaan antara data wajib pajak dalam sistem dengan kondisi di lapangan

Penulis memperoleh informasi bahwa data yang ada dalam sistem seperti alamat dan nomor telepon yang bisa dihubungi berbeda dengan kondisi yang sebenarnya dari wajib pajak di lapangan. Keadaan ini menyebabkan pihak UPTD Kota Manado mengalami kesulitan dalam menjalankan kegiatan yang berkaitan dengan administrasi wajib pajak. Dalam wawancara dijelaskan bahwa sejak UPTD Kota Manado terakhir kali melakukan kunjungan ke lapangan lewat program See Samrat Smart, hanya sekitar sepuluh persen wajib pajak yang memiliki data lapangan sesuai dengan data dalam sistem. Perbedaan pada alamat wajib pajak disebabkan oleh karena wajib pajak pindah rumah dan perbedaan pada nomor telepon wajib pajak disebabkan oleh Wajib Pajak yang mengganti nomor telepon.

Upaya Mengatasi Kendala. Merangkum hasil wawancara dengan para informan, upayaupaya yang telah dilakukan pihak UPTD Kota Manado untuk mengatasi kendala-kendala dalam penerapan tarif progresif Pajak Kendaraan Bermotor adalah sebagai berikut:

1. Sosialisasi

UPTD Kota Manado telah dan akan terus melaksanakan sosialisasi kepada masyarakat selaku wajib pajak mengenai pajak daerah secara berkala. Pihak instansi juga selalu melakukan sosialisasi tentang program-program baru dan inovasi-inovasi yang diterapkan dalam pengelolaan pajak daerah. Sosialisasi ini dilakukan dalam berbagai bentuk dan media, seperti sosialisasi verbal, lewat media cetak, media massa, dan lain sebagainya.

2. Layanan keberatan

Untuk wajib pajak yang keberatan karena penetapan kepemilikan kendaraan bermotor yang tidak seharusnya yang menyebabkan meningkatnya tarif Pajak Kendaraan Bermotor yang dikenakan, upaya yang ditempuh yaitu dengan menghimbau wajib pajak untuk membuat surat pernyataan bahwa kendaraan yang dimaksud sudah dijual atau rusak atau hilang sehingga kendaraan tersebut akan dibebaskan dari kepemilikan wajib pajak dan diblokir dari sistem. Ketika pemilik yang baru dari kendaraan tersebut akan membayar pajak, karena kendaraan tersebut sudah terblokir maka yang bersangkutan harus menghadap bagian sengketa dan akan dihimbau untuk melakukan balik nama.

3. Penerapan program baru dalam rangka meningkatkan kualitas pelayanan

UPTD Kota Manado telah dan akan terus menerapkan program-program baru dalam rangka meningkatkan kualitas pelayanan. Program-program tersebut adalah:

a) Call Center

Call Center adalah layanan via telepon yang melayani wajib pajak guna penyebaran informasi mengenai administrasi wajib pajak. Dari program ini juga wajib pajak akan diingatkan beberapa waktu sebelum jatuh tempo pembayaran pajak demi mencapai target penerimaan Pajak Daerah.

b) $e$-Samsat

$e$-Samsat adalah fasilitas layanan administrasi yang memanfaatkan teknologi internet. Layanan yang disediakan berupa pelayanan pembayaran Pajak Kendaraan Bermotor, 
Bea Balik Nama Kendaraan Bermotor dan Sumbangan Wajib Dana Kecelakaan Lalu Lintas Jalan.

c) Aplikasi Kendaraan Bermotor

Aplikasi Kendaraan Bermotor bernama "Info Pajak Kendaraan Sulut" juga merupakan bagian dari $e$-Samsat yang berisi layanan penyediaan informasi mengenai data kendaraan dan data Pajak Kendaraan Bermotor dari setiap kendaraan bermotor yang terdaftar pada Unit Pelaksana Teknis Daerah Kota Manado. Aplikasi ini tersedia untuk diunduh dari Google Play Store.

d) Samsat Drive Thru

Samsat Drive Thru adalah layanan bidang administrasi Pajak Kendaraan Bermotor di mana Wajib Pajak yang datang tidak perlu turun dari kendaraannya untuk mendapatkan pelayanan karena wajib pajak akan langsung dilayani di tempat khusus berupa pos untuk perhentian kendaraan. Waktu pelayanan pada Samsat Drive Thru kurang lebih lima menit.

4. Pembaharuan data dalam sistem

Dalam rangka memperbaharui data dalam sistem, UPTD Kota Manado tengah menjalankan program See Samrat Smart. Lewat program ini, pihak instansi akan turun langsung ke lapangan untuk memeriksa ketepatan data yang terdapat dalam sistem dengan data yang ada di lapangan. Untuk data yang ditemukan berbeda, maka data dalam sistem akan langsung diubah dengan data baru yang diperoleh di lapangan.

\subsection{Pembahasan}

Penerapan Tarif Progresif Pajak Kendaraan Bermotor pada Unit Pelaksana Teknis Daerah Kota Manado.

Aspek Nama, Objek dan Subjek Pajak Kendaraan Bermotor. Informasi mengenai perlakuan kebijakan tarif progresif Pajak Kendaraan Bermotor terhadap pengusaha kena pajak tidak ditemukan dalam Peraturan Daerah Provinsi Sulawesi Utara Nomor 7 Tahun 2011 tentang Pajak Daerah. Melalui hasil wawancara, diketahui bahwa wajib pajak badan dibebaskan dari pengenaan tarif progresif Pajak Kendaraan Bermotor. "Pengusaha kena pajak akan tetap dikenakan tarif progresif, terkecuali untuk wajib pajak badan yang dibebaskan dari pengenaan tarif progresif Pajak Kendaraan Bermotor." (Aprine Siwi, wawancara, 2018). Jelas bahwa pemerintah mendukung para pengusaha kena pajak yang tergolong wajib pajak badan lewat pemberian fasilitas pembebasan tarif progresif Pajak Kendaraan Bermotor. Penjual kendaraan bermotor tentu merasakan dampak baik langsung maupun tidak langsung. Hanya kalangan bisnis yang bergerak dalam jual-beli mobil yang akan merasakan dampak langsung kebijakan ini terhadap profit mereka, dan jumlah bisnis kendaraan bermotor relatif kecil dibandingkan dengan jumlah keseluruhan basis pengusaha kena pajak. Salah satu tujuan dari penerapan kebijakan ini adalah untuk meminimalisir kemacetan, dan aktivitas bisnis sangat bergantung pada penggunaan kendaraan bermotor. Lewat kebijakan ini diharapkan para pengusaha kena pajak akan merasakan manfaatnya. Dalam wawancara dengan Bapak Alfrets Owu juga dikatakan bahwa ada beberapa jenis kendaraan bermotor yang tidak terkena tarif progresif Pajak Kendaraan Bermotor, seperti pick-up, truk, dan angkutan umum. Mobil-mobil tipe ini banyak dimiliki oleh Usaha Mikro, Kecil dan Menengah (UMKM).

Aspek Dasar Pengenaan, Tarif dan Cara Penghitungan Pajak Kendaraan Bermotor. 3 hal yang dibahas dalam aspek ini yakni peninjauan Harga Pasaran Umum secara berkala, sistem dan prosedur pelayanan pembayaran PKB dan BBN-KB, dan kepemilikan kendaraan bermotor.

1. Peninjauan Harga Pasaran Umum secara Berkala

UPTD Kota Manado telah menerapkan peninjauan Harga Pasaran Umum secara berkala atau secara tahunan sesuai dengan Peraturan Daerah Nomor 7 Tahun 2011 tentang Pajak Daerah. Hal ini penting karena akan menentukan Nilai Jual Kendaraan Bermotor untuk 
menghitung Dasar Pengenaan Pajak. Dalam masyarakat terdapat kendaraan-kendaraan yang sudah tidak termasuk dalam daftar kendaraan bermotor. "Untuk data Harga Pasaran Umum kendaraan bermotor, UPTD Kota Manado berkiblat ke Peraturan Menteri Dalam Negeri (Permendagri) yang dijabarkan ke Peraturan Gubernur (Pergub), dan itu dimutakhirkan melalui coding atau pengkodean kendaraan bermotor. Untuk kendaraan tua atau yang sudah tidak terdaftar dalam coding, akan diperiksa berapa pajak terakhir saat kendaraan masih terdaftar, atau selain itu jumlah tahun dari tahun terakhir kode kendaraan tersebut masih terdaftar sampai pada tahun pemeriksaan dikalikan dengan 5\% dan ditambahkan dengan pajak terakhir." (Aprine Siwi, wawancara, 2018). Lewat manajemen data Harga Pasaran Umum ini, pemerintah memiliki pengawasan terhadap peredaran kendaraan bermotor baik baru maupun bekas, yang tentunya akan berhubungan dengan penetapan tarif pajak kendaraan bermotor serta tujuan pembuatan kebijakan tarif progresif ini, yaitu menekan pertumbuhan jumlah kendaraan bermotor.

2. Sistem dan Prosedur Pelayanan Pembayaran PKB dan BBN-KB

Sistem dan prosedur pelayanan pembayaran PKB dan BBN-KB pada UPTD Kota Manado yang dijelaskan dalam tabel 2.1 telah disosialisasikan kepada wajib pajak lewat media cetak, agar supaya wajib pajak mengetahui alur data, siapa saja pelaksana yang terlibat langsung, kelengkapan berkas, waktu, output yang dihasilkan dari setiap tahapan dalam prosedur, serta keterangan-keterangan lain yang diperlukan. Sistem administrasi pada UPTD Kota Manado telah terintegrasi dengan kantor pusat. Sistem dan prosedur pelayanan pembayaran PKB dan BBN-KB pada UPTD Kota Manado dinilai sudah efisien karena mengacu pada peraturan perundang-undangan dan syarat efisiensi pemungutan pajak. Syarat pemungutan pajak harus efisien (syarat finansiil) dimana sesuai dengan fungsi budgetair pajak, biaya pemungutan pajak harus dapat ditekan sehingga lebih rendah dari hasil pemungutannya (Mardiasmo, 2018 : 2). UPTD Kota Manado juga melarang penggunaan calo dalam pengurusan administrasi kendaraan bermotor. Penerapan program baru dalam meningkatkan kualitas administrasi dalam pelayanan juga mendukung efisiensi pemungutan pajak.

3. Kepemilikan Kendaraan Bermotor

Pada UPTD Kota Manado, kepemilikan kendaraan bermotor ditetapkan berdasarkan nama dan/atau alamat yang sama. Namun dalam wawancara dengan salah satu informan, terdapat perbedaan."Kami menetapkan kepemilikan berdasarkan nama dan alamat." (Alfrets Owu, wawancara, 2018). Meninjau peraturan yang ada, dalam pasal 8 Peraturan Daerah Provinsi Sulawesi Utara Nomor 7 Tahun 2011 tentang Pajak Daerah, tertulis bahwa "Kepemilikan kendaraan bermotor didasarkan atas nama dan/atau alamat yang sama". Penggunaan kata "dan/atau" menghasilkan ketidakpastian hukum dan multitafsir dan multitafsir seperti dijelaskan penelitian-penelitian sebelumnya.

Dalam menetapkan kepemilikan kendaraan bermotor, dokumen yang digunakan sebagai acuan adalah Kartu Tanda Penduduk (KTP) dan Surat Izin Mengemudi (SIM). Dalam beberapa kondisi SIM tidak dapat digunakan. "UPTD Kota Manado menggunakan nama yang tertera pada KTP. Jika tidak memiliki KTP maka bisa menggunakan SIM, namun jika kendaraan masih baru harus menggunakan KTP, karena jika calon pemilik belum berdomisili di Sulawesi Utara, maka orang yang bersangkutan belum bisa menjadi pemilik kendaraan bermotor." (Aprine Siwi, wawancara, 2018). Penetapan kepemilikan kendaraan bermotor berdasarkan nama dan alamat pada KTP memiliki celah untuk penghindaran pajak, yakni dengan membagi kepemilikan kendaraan-kendaraan bermotor dengan orang lain sehingga terhindar dari tarif progresif. Celah ini relatif mudah untuk dilakukan oleh wajib pajak, seperti pada kota-kota lain di Indonesia. Bentuk penghindaran pajak ini tentunya mempengaruhi tujuan penerapan kebijakan, khususnya pada fungsi regulerend. 
Aspek Wilayah Pemungutan Pajak Kendaraan Bermotor. Pada UPTD Kota Manado, tarif progresif PKB tidak dikenakan atas kendaraan-kendaraan bermotor yang didaftarkan pada wilayah pemungutan yang berbeda-beda. "Tarif progresif dikenakan atas nama dan alamat yang sama. Misalnya dibeli kendaraan baru dan didaftarkan di Kota Manado. Ketika dibeli lagi kendaraan baru dan didaftarkan di Kota Tondano, maka kendaraan tersebut tidak terkena tarif progresif" (Aprine Siwi, wawancara, 2018). Peraturan ini memiliki celah yang relatif mudah bagi masyarakat untuk dapat melakukan penghindaran pajak, karena wajib pajak akan mendaftarkan kendaraan-kendaraannya pada UPTD yang berbeda-beda. Berkaitan dengan aspek kepemilikan, dengan mendaftarkan kendaraan bermotor pada wilayah pemungutan yang berbeda-beda, kepemilikan dapat dikontrol sehingga akan mengurangi progresivitas tarif yang dikenakan.

Tujuan Penerapan Tarif Progresif Pajak Kendaraan Bermotor. Dalam wawancara dengan Ibu Junita Laloan, dikatakan bahwa tujuan penerapan kebijakan ini adalah untuk meningkatkan penerimaan Pajak Kendaraan Bermotor. Tujuan ini berkaitan dengan fungsi budgetair pajak. "Pajak Kendaraan bermotor adalah sumber Pendapatan Asli Daerah terbesar. Kontribusinya (sekitar) 80 persen." (Junita Laloan, wawancara, 2018). Selain itu juga dijelaskan oleh Ibu Aprine Siwi bahwa tujuan penerapan tarif progresif Pajak Kendaraan Bermotor adalah untuk menekan pertumbuhan jumlah kendaraan bermotor. Tujuan ini berkaitan dengan fungsi regulerend pajak. Tujuan penerapan kebijakan ini serupa dengan penelitian-penelitian terdahulu pada lokasi yang berbeda-beda di Indonesia. Namun dalam penelitian di Kota Manado peneliti juga menemukan tujuan lain, yakni untuk perbaikan administrasi dalam rangka intensifikasi perpajakan yang berkaitan dengan fungsi regulerend pajak, dan untuk meningkatkan penerimaan BBN-KB yang berkaitan dengan fungsi budgetair pajak. "Tujuannya yang pertama agar supaya masyarakat ketika membeli kendaraan langsung balik nama, supaya juga aman bagi dia. Kalau sudah di balik nama atas nama dia, nanti banyak kemudahan dalam pembayaran." (Alfrets Owu, wawancara, 2018).

\section{Kendala dalam Penerapan Tarif Progresif Pajak Kendaraan Bermotor serta Upaya yang Dilakukan UPTD Kota Manado dalam Mengatasinya \\ Kendala}

1. Penyebaran informasi

Banyak wajib pajak di Kota Manado yang masih belum mengetahui tentang kebijakan tarif progresif Pajak Kendaraan Bermotor. "Kalau dari saya, ketika kami menerapkan pajak progresif, banyak masyarakat yang belum mengetahui." (Alfrets Owu, wawancara, 2018). Dalam penelitian terdahulu oleh Irwanto (2015), penurunan minat dalam membayar pajak progresif disebabkan oleh faktor kurangnya sosialisasi terhadap masyarakat. Kebijakankebijakan baru harus disosialisasikan dengan intensif, mengingat kurang maksimalnya penyebaran informasi merupakan kendala yang terjadi dalam penerapan kebijakan di beberapa kota di Indonesia. Kurangnya penyebaran informasi diyakini sebagai salah satu faktor yang menghambat penerapan tarif progresif Pajak Kendaraan Bermotor pada UPTD Kota Manado, melihat banyaknya Wajib Pajak yang masih belum mengetahui tentang kebijakan ini.

2. Kepatuhan Wajib Pajak

Pada UPTD Kota Manado, kesadaran wajib pajak untuk melakukan balik nama saat membeli kendaraan bekas masih kurang, dan ini tentunya berimbas kepada kepatuhan wajib pajak. Hal ini disebabkan oleh pendapat masyarakat bahwa tarif BBN-KB cukup besar. Pihak wajib pajak sering mengajukan keberatan, karena mengklaim bahwa penetapan tarif per kepemilikan tidak sesuai dengan kondisi wajib pajak. Penulis menemukan dua kasus terkait keberatan wajib pajak ini. Kasus yang pertama yaitu pembeli kendaraan bekas membayar tarif yang tidak seharusnya karena tarif per kepemilikan yang dikenakan masih mengacu pada 
data dari pemilik sebelumnya. Kasus yang kedua yaitu ketika wajib pajak membeli kendaraan dan dikenakan tarif per kepemilikan yang tidak seharusnya karena kendaraan lama yang telah dijual oleh wajib pajak tersebut masih terdaftar atas namanya, akibat dari pembeli yang belum melakukan balik nama.

3. Perbedaan data dalam sistem dengan kondisi sebenarnya di lapangan

Perbedaan data dalam sistem tentunya memberikan dampak buruk dalam administrasi, dan pada Unit Pelaksana Teknis Daerah Kota Manado ketepatan data dalam sistem masih sangat kurang yaitu sekitar $10 \%$ sejak pengecekan data lapangan terakhir, dengan alasan ratarata sudah dijual, hilang, rusak berat, tetapi yang terbanyak adalah sudah dijual atau pindah alamat. Akan tetapi, perbedaan informasi adalah kendala yang akan muncul seiring berjalannya waktu karena perubahan-perubahan yang terjadi pada masyarakat seperti pindah alamat, mengganti nomor telepon, dan lain sebagainya. Kualitas data pada sistem juga berdampak terhadap penerimaan, karena dapat membantu program jemput bola melalui call center dan SMS Gateway. Program terbaru yaitu See Samrat Smart dibuat untuk mengatasi masalah ini.

\section{Upaya Mengatasi Kendala}

\section{Sosialisasi}

UPTD Kota Manado telah dan akan terus melaksanakan sosialisasi di berbagai media baik media cetak, media massa, dan lain sebagainya. “... Sosialisasi terus-menerus dilakukan kepada masyarakat, karena banyak masyarakat yang tidak mengetahui tentang kebijakankebijakan pemerintah yang berlaku." (Junita Laloan, wawancara, 2018). Sosialisasi perlu dilakukan karena merupakan salah satu dari faktor-faktor yang dapat memberikan peningkatan kesadaran wajib pajak, yang telah dijelaskan sebelumnya sebagai kendala dalam penerapan tarif progresif Pajak Kendaraan Bermotor (Rahayu, 2017 : 191).

2. Layanan keberatan

Pada UPTD Kota Manado, terdapat bagian yang melayani sengketa, dengan nama Seksi Pelayanan Sengketa dan Lain-lain Pendapatan Asli Daerah. Terkait masalah penetapan tarif per kepemilikan, wajib pajak yang keberatan akan dihimbau untuk melakukan lapor jual/hilang/rusak dan pemblokiran kendaraan bermotor. Layanan keberatan ini adalah salah satu bentuk pelayanan perpajakan yang diberikan kepada wajib pajak, dan output yang diharapkan dari layanan ini adalah kondisi sistem administrasi yang baik.

3. Pembaharuan data dalam sistem

UPTD Kota Manado telah memasuki tahap awal dalam perbaikan administrasi lewat program See Samrat Smart. Melalui program ini, UPTD Kota Manado dapat langsung melakukan tindakan terhadap perbedaaan data yang ditemukan. Lewat pembaharuan data, diharapkan bahwa pengelolaan pajak akan lebih baik. Dalam wawancara dengan informan dikemukakan bahwa kedepannya UPTD Kota Manado berencana untuk terintegrasi dengan Dinas Kependudukan dan Pencatatan Sipil guna pengembangan kualitas administrasi.

4. Penerapan program baru

Unit Pelaksana Teknis Daerah Kota Manado telah menerapkan program-program baru seperti Call Center, e-Samsat, SMS Gateway, Aplikasi Kendaraan Bermotor, Samsat Drive Thru dan See Samrat Smart. Program-program baru ini merupakan perwujudan inovasi dari Satuan Kerja Perangkat Daerah (SKPD) dalam rangka meningkatkan kualitas pelayanan dan administrasi yang didalamnya termasuk efisiensi pelayanan. 


\section{KESIMPULAN DAN SARAN}

\subsection{Kesimpulan.}

berikut:

Berdasarkan hasil penelitian dan pembahasan, penulis menarik kesimpulan sebagai

1. Dalam penerapan tarif progresif Pajak Kendaraan Bermotor, subjek pajak pengusaha kena pajak diberikan fasilitas oleh Pemerintah Provinsi Sulawesi Utara berupa pembebasan dari pengenaan tarif progresif Pajak Kendaraan Bermotor. Harga Pasaran Umum kendaraan bermotor yang menjadi dasar penghitungan Dasar Pengenaan Pajak di-update secara berkala oleh UPTD Kota Manado. Pelaksanaan administrasi pada UPTD Kota Manado diawasi langsung oleh Kepala UPTD dan para Kepala Seksi serta dievaluasi secara berkala untuk menjaga kualitas pelayanan. Kepemilikan kendaraan bermotor ditetapkan berdasarkan nama dan alamat yang sama, dengan mengacu pada informasi yang tertera dalam Kartu Tanda Penduduk. Tarif progresif Pajak Kendaraan Bermotor tidak dikenakan pada kendaraan-kendaraan yang didaftarkan pada wilayah pemungutan yang berbeda-beda. Tujuan pemerintah dalam pembuatan kebijakan ini yaitu untuk menekan pertumbuhan jumlah kendaraan bermotor, kemudahan dalam administrasi, dan meningkatkan pendapatan daerah lewat Pajak Kendaraan Bermotor dan Bea Balik Nama Kendaraan Bermotor II.

2. Kendala-kendala yang dihadapi yakni kurangya penyebaran informasi tentang kebijakan, kurangnya kepatuhan wajib pajak, dan perbedaan antara data wajib pajak dalam sistem dan kondisi di lapangan.

3. Berbagai upaya dalam menghadapi kendala yang ada yakni sosialisasi tentang pajak dan program-program baru, layanan keberatan untuk kendala penetapan kepemilikan kendaraan bermotor, penerapan program-program baru dalam rangka peningkatan kualitas pelayanan yaitu Call Center, e-Samsat, SMS Gateway, Aplikasi Kendaraan Bermotor, Samsat Drive-Thru dan pembaharuan data Wajib Pajak dalam sistem lewat program See Samrat Smart.

\subsection{Saran.}

Berdasarkan kesimpulan, penulis memberikan saran-saran kepada Pemerintah Daerah Sulawesi Utara sebagai berikut:

1. Menerapkan penetapan kepemilikan berdasarkan nama dan alamat yang sama, dengan dokumen pembantu berupa KTP dan Kartu Keluarga sehingga dapat mengurangi celah penghindaran pajak dengan menyebarkan kepemilikan pada anggota keluarga.

2. Mengintegrasikan data pada UPTD di setiap wilayah pemungutan yang ada di Indonesia, sehingga dapat mengurangi celah penghindaran pajak dengan mendaftarkan kendaraankendaraannya pada wilayah pemungutan yang berbeda-beda.

3. Meningkatkan progresivitas tarif dalam kebijakan tarif progresif Pajak Kendaraan Bermotor, agar dapat lebih mendorong fungsi regulerend dari kebijakan tarif progresif Pajak Kendaraan Bermotor.

4. Lebih gencar melakukan sosialisasi tentang pajak daerah khususnya Pajak Kendaraan Bermotor, untuk meningkatkan pemahaman masyarakat.

5. Melakukan penanaman paham cinta negara lewat bayar pajak sejak usia dini, yakni pada pendidikan sekolah.

6. Lebih gencar melakukan pemeriksaan langsung di lapangan, sehingga kualitas data dalam sistem dapat terjaga.

7. Memberlakukan sistem denda terhadap wajib pajak yang terlambat melaporkan perubahan data. 


\section{DAFTAR PUSTAKA}

Agoes, Sukrisno dan Trisnawati, Estralita. 2013. Akuntansi Perpajakan. Edisi 3. Salemba Empat. Jakarta.

Azizah, Ajeng. 2014. Analisis Implementasi dan Alternatif Kebijakan Tarif Progresif Pajak Kendaraan Bermotor DKI Jakarta. Skripsi. Fakultas Ilmu Sosial dan Ilmu Politik Universitas Indonesia. Depok.

Gnap, Jozef, dan Konečný, Vladimír. 2015. Motor Vehicle Taxation in the Slovak Republic and its Impacts in the Context of Fiscal Decentralization. Procedia Economics and Finance 34: 344-351.

Indrawati, Chipuk. 2013. Implementasi Program Pajak Progresif di Dinas Pendapatan Jawa Timur. Skripsi. Program Studi Ilmu Administrasi Negara Fakultas Ilmu Sosial dan Ilmu Politik Universitas Airlangga. Surabaya.

Irwanto, Rudi. 2015. Analisis Penerapan Pajak Progresif terhadap Wajib Pajak Kendaraan Bermotor (Studi Kasus Samsat Kota Makassar). Skripsi. Jurusan Akuntansi Fakultas Ekonomi dan Bisnis Universitas Hasanuddin. Makassar.

Kieso, D.E., Weygandt, J.J. dan Warfield, T.D. 2016. Intermediate Accounting, $16^{\text {th }}$ Edition. John Wiley and Sons Inc. New York, USA.

Mardiasmo. 2018. Perpajakan. Edisi Revisi. Penerbit Andi. Yogyakarta.

Peraturan Daerah Provinsi Sulawesi Utara Nomor 7 Tahun 2011 tentang Pajak Daerah. Pemerintah Daerah Sulawesi Utara. Manado.

Rahayu, Siti. 2017. Perpajakan (Konsep dan Aspek Formal). Rekayasa Sains. Bandung.

Sugiyono. 2017. Metode Penelitian Kebijakan: Pendekatan Kuantitatif, Kualitatif, Kombinasi, $R \& D$, dan Penelitian Evaluasi. Alfabeta. Bandung.

Undang-Undang Republik Indonesia Nomor 28 Tahun 2009 tentang Pajak Daerah dan Retribusi Daerah. Tambahan Lembaran Negara Republik Indonesia Nomor 5049.

Waluyo. 2014. Perpajakan Indonesia. Buku 1.Edisi 11. Salemba Empat. Jakarta. 